\title{
EphA4 Regulates Neuroblast and Astrocyte Organization in a Neurogenic Niche
}

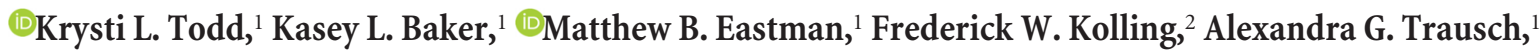 \\ Craig E. Nelson, ${ }^{2}$ and ${ }^{\oplus}$ Joanne C. Conover ${ }^{1}$ \\ ${ }^{1}$ Department of Physiology and Neurobiology and ${ }^{2}$ Department of Molecular and Cell Biology, University of Connecticut, Storrs, Connecticut 06269
}

\begin{abstract}
Significant migration cues are required to guide and contain newly generated rodent subventricular zone (SVZ) neuroblasts as they transit along the lateral ventricles and then through the anterior forebrain to their ultimate site of differentiation in the olfactory bulbs (OBs). These cues enforce strict neuroblast spatial boundaries within the dense astroglial meshwork of the SVZ and rostral migratory stream (RMS), yet are permissive to large-scale neuroblast migration. Therefore, the molecular mechanisms that define these cues and control dynamic interactions between migratory neuroblasts and surrounding astrocytes are of particular interest. We found that deletion of EphA4 and specifically ablation of EphA4 kinase activity resulted in misaligned neuroblasts and disorganized astrocytes in the RMS/SVZ, linking EphA4 forward signaling to SVZ and RMS spatial organization, orientation, and regulation. In addition, within a 3 week period, there was a significant reduction in the number of neuroblasts that reached the $\mathrm{OB}$ and integrated into the periglomerular layer, revealing a crucial role for EphA4 in facilitating efficient neuroblast migration to the OB. Single-cell analysis revealed that EPHA4 and its EFN binding partners are expressed by subpopulations of neuroblasts and astrocytes within the SVZ/RMS/OB system resulting in a cell-specific mosaic, suggesting complex EphA4 signaling involving both homotypic and heterotypic cell-cell interactions. Together, our studies reveal a novel molecular mechanism involving EphA4 signaling that functions in stem cell niche organization and ultimately neuroblast migration in the anterior forebrain.
\end{abstract}

Key words: astrocyte; migration; neuroblast; olfactory bulb; rostral migratory stream; subventricular zone

\section{Significance Statement}

The subventricular zone neurogenic stem cell niche generates highly migratory neuroblasts that transit the anterior forebrain along a defined pathway to the olfactory bulb. Postnatal and adult brain organization dictates strict adherence to a narrow migration corridor. Subventricular zone neuroblasts are aligned in tightly bundled chains within a meshwork of astrocytes; however, the cell-cell cues that organize this unique, cell-dense migration pathway are largely unknown. Our studies show that forward signaling through the EphA4 tyrosine kinase receptor, mediated by ephrins expressed by subpopulations of neuroblasts and astrocytes, is required for compact, directional organization of neuroblasts and astrocytes within the pathway and efficient transit of neuroblasts through the anterior forebrain to the olfactory bulb.

\section{Introduction}

The rodent subventricular zone (SVZ) stem cell niche lies along the lateral walls of the brain's lateral ventricles and maintains its

\footnotetext{
Received Dec. 5, 2016; revised Feb. 10, 2017; accepted Feb. 13, 2017.

Author contributions: K.L.T., K.L.B., M.B.E., F.W.K., and J.C.C. designed research; K.L.T., K.L.B., M.B.E., and A.G.T. performed research; C.E.N. contributed unpublished reagents/analytic tools; K.L.T., K.L.B., M.B.E., F.W.K., and A.G.T. analyzed data; K.L.T. and J.C.C. wrote the paper.

This work was supported by National Institutes of Health/National Institute of Neurological Disorders and Stroke R01NS50338. We thank Joshua Klein for illustrating our theoretical model; Patrick Malloy for assistance with creation of the Euler diagrams in Figure 5; and Stephen Daniels for assistance with electron microscopy as presented in Figure 1.

The authors declare no competing financial interests.

Correspondence should be addressed to Dr. Joanne C. Conover, Department of Physiology and Neurobiology, University of Connecticut, 75 North Eagleville Road, Unit 3156, Storrs, ‘T 06269. E-mail: joanne.conover@uconn.edu. DOI:10.1523/JNEUROSCI.3738-16.2017

Copyright $\odot 2017$ the authors $\quad 0270-6474 / 17 / 373331-11 \$ 15.00 / 0$
}

regenerative capacity throughout life (Gage, 2000; Braun and Jessberger, 2014; Conover and Todd, 2016; Lim and AlvarezBuylla, 2016). Within this tightly regulated niche environment, neuroblasts migrate along the lateral ventricles as densely packed chains and then transit the anterior forebrain via the rostral migratory stream (RMS), en route to the olfactory bulbs (OBs) (Luskin, 1993; Lois et al., 1996; Capilla-Gonzalez et al., 2015; Liang et al., 2016). The SVZ and RMS contain a unique organization of densely packed astrocytes that form a meshwork around the neuroblasts (Doetsch and Alvarez-Buylla, 1996; Lois et al., 1996; Alvarez-Buylla and Lim, 2004), effectively restricting highly migratory cells to the SVZ/RMS core (Gengatharan et al., 2016). In human infants, newly described robust migration pathways (RMS and a unique medial migratory stream) located by the anterior portion of the lateral ventricles supply inhibitory neu- 
rons to the olfactory bulb and frontal lobe, including the prefrontal cortex (Sanai et al., 2007, 2011; Paredes et al., 2016). These pathways display an organization reminiscent of the rodent RMS with chains of migrating neurons flanked by astrocytes. The molecular players responsible for the dynamic organization of neuroblasts and astrocytes in postnatal and adult (in the rodent) neuroblast migration, and the cell-cell mechanisms that allow efficient migration of neuroblasts through the anterior forebrain are unclear. However, cell-cell-mediated signaling resulting in repulsion and/or attraction is likely to be a key regulator.

In the adult rodent SVZ, Eph-ephrin interactions have been implicated in the regulation of neuroblast chain formation (Conover et al., 2000), cell cycle rate and survival (Holmberg et al., 2005; Ricard et al., 2006), progenitor cell proliferation (Conover et al., 2000; Theus et al., 2010; del Valle et al., 2011), and neuronal fate commitment (Aoki et al., 2004; Yin et al., 2004). The Eph receptors comprise the largest known family of receptor tyrosine kinases. Along with their ligands, they are divided into A and B classes, based on homology and binding affinities. EphA receptors (1-8, 10 in mammals) typically bind glycosylphosphatidylinositol-linked ephrinA ligands (1-6), whereas EphB receptors $(1-4,6)$ prefer single-pass transmembrane ephrinB molecules (1-3) (Klein, 2001). Eph-ephrin signaling requires cell-cell contact and can proceed either unidirectionally through the receptor-bearing cell ("forward" or "classical" signaling) or the ligand-bearing cell ("reverse" signaling), or bidirectionally through both the receptor-bearing and ligand-bearing cells (Martínez and Soriano, 2005; Pasquale, 2008). Although it was previously thought that Eph-ephrin signaling mediated primarily contact-repulsive interactions, evidence suggests adhesive, contactattractant mechanisms also occur (Holmberg et al., 2005; Pasquale, 2008; Cramer and Miko, 2016; Kania and Klein, 2016).

Because the EphA4 receptor is robustly expressed by cells in the SVZ (Conover et al., 2000) and has the unique ability to bind most ephrinA and ephrinB ligands, we proposed that it alone may have broad ability to control SVZ/RMS functions. We found that, in the absence of EphA4, and more specifically forward signaling through its kinase domain, populations of SVZ and RMS neuroblasts were loosely aligned, lacked compact bundling of fasciculated chains, and displayed aberrant migration into neighboring parenchymal brain structures. Disoriented neuroblast migration in EphA4 ${ }^{-1-}$ mice ultimately resulted in fewer neuroblasts reaching the periglomerular layer (PGL) of the OB. Single-cell analysis revealed a complex pattern of EPHA4 and EFN expression in which $E F N^{\prime} s$ were coexpressed with each other and/or with EPHA4 on both neuroblasts and astrocytes. This indicated that both homotypic (neuroblast-neuroblast, astrocyte-astrocyte) and heterotypic (neuroblast-astrocyte) cell-cell interactions could facilitate EphA4 functions in this region. In summary, our findings reveal a novel EphA4-dependent forward signaling mechanism essential for the regulated control of neuroblast and astrocyte organization within the SVZ and RMS. These results provide the first example that kinase-dependent EphA4 signaling is necessary for the unique organization of the postnatal and adult SVZ/RMS neurogenic niche and this strict organization supports efficient neuroblast migration.

\section{Materials and Methods}

Animals. EphA4 $4^{+/+}$and EphA4 $4^{-/-}$(Helmbacher et al., 2000), a gift from Dr. Maria J. Donoghue, Georgetown University, were housed and bred in our vivarium. EphA4 $4^{-1-}$ mice exhibit complete atrophy of the peroneal muscles of the hindlimbs, resulting in a "club-foot" phenotype and abnormal gait. These deficiencies are due to absence of the peroneal nerve, caused by misrouting of axons emerging from L3, L4, and L5 spinal nerves and sciatic plexus in the absence of EphA4 (Helmbacher et al., 2000). In all other aspects, EphA4 ${ }^{-1-}$ mice mature normally and live through adulthood. Kinase-dead (KD)-EphA4 ${ }^{\mathrm{eGFP}}$ mice, displaying a similar phenotype to EphA4 $4^{-1-}$ mice (Kullander et al., 2001), were received as a gift from Drs. Klas Kullander and Christiane Peuckert (Uppsala University). hGFAP:mRFP1 (Hirrlinger and Dringen, 2005), a gift from Dr. Frank Kirchhoff, B6-Tg(GFAP-Cre/ERT2)1Kdmc (Casper et al., 2006), a gift from Dr. Ken McCarthy (University of North Carolina at Chapel Hill), and B6.Cg-Gt(ROSA)26Sor ${ }^{\text {tm 14(CAG-tdTomato }) H z e} / J$ (ROSA26-tdT; The Jackson Laboratory) mice were also housed and bred in our vivarium. Animal procedures were performed under protocols approved by the Institutional Animal Care and Use Committee of the University of Connecticut and conform to National Institute of Health and Association for Assessment and Accreditation of Laboratory Animal Care guidelines.

Immunofluorescence. Male mice were anesthetized with isoflurane (Butler Schein) and perfused transcardially with $0.9 \%$ saline followed by $4 \%(\mathrm{v} / \mathrm{v})$ PFA (Electron Microscopy Sciences) in $0.1 \mathrm{M} \mathrm{PBS,} \mathrm{pH} \mathrm{7.4.} \mathrm{Brains} \mathrm{were} \mathrm{re-}$ moved and postfixed in $4 \%$ PFA overnight (at least $12 \mathrm{~h}$ ) followed by three 40 min washes in PBS. Brains were sectioned $(50 \mu \mathrm{m})$ on a vibratome (VT1000S; Leica) and then blocked for $1 \mathrm{~h}$ at room temperature with $10 \%(\mathrm{v} / \mathrm{v})$ normal horse or goat serum (Thermo Fisher Scientific) in PBS with $0.1 \%$ $0.5 \%$ Triton X-100 (Sigma). Tissue sections were incubated overnight at $4^{\circ} \mathrm{C}$ with primary antibodies prepared in blocking solution using the following concentrations: goat anti-doublecortin (Dcx) 1:200 (Santa Cruz Biotechnology, RRID: AB_2088494), guinea pig anti-Dcx 1:1000 (Millipore, RRID: AB_1586992), rabbit anti-Dcx 1:200 (Santa Cruz Biotechnology, AB_2088488), rabbit anti-GFAP 1:1000 (DAKO, RRID: AB_10013382), mouse anti-GFAP 1:400 (Millipore, RRID: AB_2109815), rat anti-GFAP clone 2.2B10 1:250 (Thermo Fisher Scientific, RRID: AB_86543), goat antiPECAM-1 1:50 (Santa Cruz Biotechnology, RRID: 632174), rabbit antiEphA4 1:50 (Abcam, RRID: AB_304857), rat anti-EphA4 (Abcam, RRID: AB_2099346), mouse anti-EphA4 1:50 (Thermo Fisher Scientific, RRID: AB_2533301), goat anti-EphA4 1:20 (R\&D Systems, AB_2099371), rabbit anti-ephrinA2 1:50 (Santa Cruz Biotechnology, RRID: AB_631409), rabbit anti-ephrinA3 1:50 (Santa Cruz Biotechnology, RRID: AB_2097777), rabbit anti-ephrinA5 1:50 (Santa Cruz Biotechnology, RRID: AB_2097911), or rabbit anti-ephrinB1/2/3 1:50 (Santa Cruz Biotechnology, RRID: AB_631413). Sections were then washed 3 times for 10 min each with $0.1 \%$ Triton X-100 in PBS and then incubated $1 \mathrm{~h}$ at room temperature with appropriate fluorescent secondary antibodies (1:1000 in blocking solution; AlexaFluor, Thermo Fisher Scientific). Following antibody treatment, tissue samples were washed 3 times for 10 min each in PBS, counterstained for cell nuclei with $10 \mathrm{mg} / \mathrm{ml}$ DAPI (Thermo Fisher Scientific, RRID: AB_2629482) for $5 \mathrm{~min}$, mounted onto slides, and coverslipped using Aqua-Poly/Mount (Polysciences).

For whole-mount preparations, the entire lateral wall of both lateral ventricles was removed, as previously described (Doetsch and AlvarezBuylla, 1996). Whole mounts of the lateral wall were washed, blocked, and then incubated with primary and secondary antibody solutions as described above.

Whole mounts were imaged with a Zeiss Axioskop 2+ microscope (Carl Zeiss) and Retiga 1300 EX digital camera (Q-Imaging System). Vibratome sections were imaged with a Leica TCS SP2 confocal system together with a Leica DMIRE2 microscope and Leica confocal software or with a Zeiss Imager.M2 microscope with ApoTome (Carl Zeiss) using Stereo Investigator software (MBF Bioscience) and Orca-R2 digital camera (Hamamatsu Photonics). Images were processed using ImageJ (National Institutes of Health) and Photoshop CS (Adobe).

Electron microscopy. Male mice were perfused transcardially with $0.9 \%$ saline, followed by $2 \% \mathrm{PFA} / 2.5 \%$ glutaraldehyde in $0.1 \mathrm{M}$ phosphate buffer (PB), pH 7.4. Heads were postfixed by immersion overnight in $2 \%$ $\mathrm{PFA} / 2.5 \%$ glutaraldehyde in $0.1 \mathrm{M} \mathrm{PB}$; brains were removed and washed in PB three times for $40 \mathrm{~min}$ each. Three $300 \mu \mathrm{m}$ sections of the anterior forebrain were cut with a vibratome, and the area surrounding the ventricle was removed from each. Briefly, sections were postfixed with $2 \%$ osmium tetroxide in $0.1 \mathrm{M}$ PB for $1.25 \mathrm{~h}$, unpinned, and dehydrated through a graded ethanol series. Sections were en bloc stained in $2 \%$ uranyl acetate at the $70 \%$ ethanol step for $1.5 \mathrm{~h}$. After dehydration, sec- 
tions were washed twice in propylene oxide and embedded in a SPI-PON 812 (SPI Supplies)/Araldite 506 (Ernest F. Fullam). After polymerization, thin sections were cut with a diamond knife, placed onto Formvarcoated slot grids, and heavy metal stained with uranyl acetate and lead citrate. Electron micrograph montages were constructed as previously described (Doetsch et al., 1997; Baker et al., 2006; Luo et al., 2006).

RMS cross-sectional area measurements. Fifty-micrometer coronal sections from adult male mice were immunolabeled for Dcx (Santa Cruz Biotechnology), and fluorescent images were taken between coordinates $1.75 \mathrm{~mm}$ and $3.00 \mathrm{~mm}$ anterior to bregma using a Zeiss Imager.M2 microscope (Carl Zeiss) and an Orca-R2 digital camera (Hamamatsu Photonics). The Dcx-immunoreactive region of the RMS from every other section was traced using stereology software (Stereo Investigator, MBF Biosciences), and contours were averaged. Six animals were used for each group $\left(E p h A 4^{+/+}, E p h A 4^{-/-}\right.$, and KD-EphA4 $\left.{ }^{e G F P / e G F P}\right)$. Statistical significance was evaluated using one-way ANOVA.

To examine the RMS cross-sectional area during the period of RMS reorganization in perinatal mice, $50 \mu \mathrm{m}$ coronal sections were immunolabeled as described above, and fluorescent images were taken between the anterior edge of the lateral ventricle and the caudal end of the OB to include the entire RMS for mice of ages P6 and P12. Three mice were used for each group $\left(E p h A 4^{+/+}, E p h A 4^{-/-}\right.$, and $\left.K D-E p h A 4^{e G F P / e G F P}\right)$ at each age examined. The average cross-sectional area at each age was calculated by tracing the $\mathrm{Dcx}^{+}$area of every other tissue section using Stereo Investigator, as described above, and statistically significant differences were evaluated using one-way ANOVA.

5-Ethynyl-2'-deoxyuridine (EdU) Immunofluorescence and quantification. Equal numbers of adult male and female mice were injected once with $150 \mathrm{mg}$ EdU/kg followed by a second injection of $100 \mathrm{mg} \mathrm{EdU/kg}$ $24 \mathrm{~h}$ later. At $21 \mathrm{~d}$ following the second injection, mice were perfused transcardially with $0.9 \%$ saline followed by $4 \%(\mathrm{v} / \mathrm{v})$ PFA (Electron Microscopy Sciences) in 0.1 M PBS. Brains were removed and postfixed in $4 \%$ PFA overnight followed by three 40 min washes in PBS. Brains were sectioned coronally $(50 \mu \mathrm{m})$, and EdU was visualized using the Click-It EdU AlexaFluor-647 Imaging Kit according to the manufacturer's instructions. Sections were imaged (Axioskop 2+, Zeiss), and EdU ${ }^{+}$cells were counted in coronal sections of the OB, RMS, and SVZ using ImageJ (National Institutes of Health). Every fifth slice was analyzed beginning at $4.74 \mathrm{~mm}$ and ending at $-0.14 \mathrm{~mm}$ relative to bregma. Six mice from

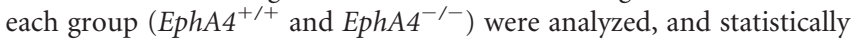
significant differences were determined using an unpaired $t$ test.

BrdU immunofluorescence and quantification. Mice were injected with $300 \mathrm{mg} \mathrm{BrdU/kg} 2 \mathrm{~h}$ before perfusion. BrdU immunostaining of $50 \mu \mathrm{m}$ sections was conducted as described previously (Cameron and McKay, 2001). Briefly, sections were mounted on slides, heated in $0.1 \mathrm{M}$ citric acid, $\mathrm{pH}$ 6.0, for antigen retrieval, and treated with trypsin and $2 \mathrm{M}$ hydrochloric acid for $1 \mathrm{~h}$. Sections were then incubated with mouse anti-BrdU 1:100 (BD Biosciences, RRID: AB_10015222) and rabbit antiKi67 1:1000 (Novocastra; Leica Biosystems, RRID: AB_442102) followed by the appropriate fluorescent secondary antibodies ( $1: 1000$ in blocking solution; AlexaFluor, Thermo Fisher Scientific). Sections were imaged (Axioskop 2+, Zeiss), and the $\mathrm{BrdU}^{+}$and $\mathrm{Ki}^{+} 7^{+}$cells were counted in coronal sections of the SVZ using Openlab 3.1.5 imaging software (Improvision) in 34 anterior forebrain sections $(50 \mu \mathrm{m})$, from coordinates 0.5-1.4 anterior, relative to bregma. Three mice were used for each group, and statistical analyses were performed using an unpaired $t$ test.

Caspase-3 quantification. Fixed coronal sections, $50 \mu \mathrm{m}$ thick, were immunostained with anti-caspase-3 (R\&D Systems, RRID: AB_2243952) to label apoptotic cells. Caspase- $3^{+}$cells in the SVZ were counted in 22 sections between coordinates $0.5-1.4$ anterior/posterior, relative to bregma. In the RMS and OB, caspase $-3^{+}$cells were counted in every section within the entire region for both structures. At least three mice were used for each group. Statistical analyses were performed using an unpaired $t$ test.

$q R T-P C R$. The RMS was dissected from two male mice, minced, and combined followed by RNA extraction using the RNeasy Mini kit (QIAGEN) according to the manufacturer's instructions. cDNA was prepared with the SuperScriptIII First-Strand cDNA synthesis kit (Thermo Fisher Scientific) using random hexamer primers according to the manufacturer's instructions. qRT-PCR was performed on a Bio-Rad C1000 thermal cycler with CFX96 Real-Time system using the following mouse specific TaqMan assays (20×; Thermo Fisher Scientific): Gapdh (Mm99999915_g1), EPHA4 (Mm00433056_m1), EFNA1 (Mm01212795_m1), EFNA2 (Mm004330 11_m1), EFNA3 (Mm01212723_g1), EFNA4 (Mm00433013_m1), EFNA5 (Mm01237700_m1), EFNB1 (Mm00438666_m1), EFNB2 (Mm0043 8670_m1), and EFNB3 (Mm00433016_m1). Data were analyzed with the Bio-Rad CFX Manager software. A total of 6 mice were analyzed, and statistically significant differences were evaluated using one-way ANOVA. Gapdh served as a reference gene for each sample.

Single-cell isolation and lysis. Single-cell suspensions of neuroblasts and astrocytes were isolated per experiment from two male P25 hGFAP: mRFP1 mice (Hirrlinger and Dringen, 2005) and two male P13 B6- Tg$(G F A P-C r e / E R T 2) 1 K d m c \times$ ROSA26-tdT mice (all $\mathrm{GFAP}^{+}$cells fluoresce red), respectively. Cre was induced in B6-Tg(GFAP-Cre/ $E R T 2) 1 K d m c \times R O S A 26-t d T$ mice by daily intraperitoneal injection (P6-P8) of $0.2 \mathrm{mg}$ 4-hydroxytamoxifen (Sigma). The region of the anterior forebrain containing the RMS was dissected, minced, and digested in $2.5 \mathrm{mg} / \mathrm{ml}$ protease XXIII (from Aspergillus melleus; Sigma) in high sucrose dissociation solution ( $30 \mathrm{~mm} \mathrm{Na}_{2} \mathrm{SO}_{4}, 2 \mathrm{~mm} \mathrm{~K}_{2} \mathrm{SO}_{4}, 10$ mM HEPES, $185 \mathrm{~mm}$ sucrose, $10 \mathrm{~mm}$ glucose, $0.5 \mathrm{mM} \mathrm{CaCl}_{2}, 6 \mathrm{mM} \mathrm{MgCl}_{2}$, and $5 \mathrm{~mm}$ ascorbic acid, $\mathrm{pH} 7.4$ ) for $10 \mathrm{~min}$ at $34^{\circ} \mathrm{C}$. Digested tissue was collected by centrifugation and resuspended in high sucrose dissociation solution with $1 \%$ BSA and $1 \mathrm{mg} / \mathrm{ml}$ trypsin inhibitor from chicken egg white (TI; Sigma). This was repeated twice with chilled high sucrose dissociation solution with $1 \%$ BSA and $1 \mathrm{mg} / \mathrm{ml}$ TI. Suspensions were then sequentially triturated using a series of flame-polished glass pipettes of progressively decreasing bore diameter $(\sim 300-100 \mu \mathrm{m})$ and then passed through 70 and $40 \mu \mathrm{m}$ mesh filters (BD Biosciences) to remove debris and cell clumps. Myelin was removed using magnetically conjugated anti-myelin removal beads (Miltenyi) according to the manufacturer's instructions. Isolation of single cells via FACS was performed on a BD FACSAria II system operated by FACSDiva software, and single cells were sorted directly into a 96-well plate (one cell/well) containing lysis buffer with the following contents in each well: $0.25 \mu$ l IGEPAL CA-630 (5\%; Sigma), $0.25 \mu$ l Rnasin Plus (Promega), $1 \mu \mathrm{l}$ PBS, and $1 \mu$ l of a TaqMan pooled assay $(0.2 \times$ of each assay). An unbiased sort was conducted when isolating neuroblasts, and astrocytes were isolated based on tdTomato fluorescence. In all cases, debris was excluded using a sort gate based on forward and side scatter amplitude, and doublet events were excluded using sort gates of forward and side scatter pulse width versus height.

Reverse transcription, preamplification, and gene expression analysis. The 96-well plates containing isolated single cells in lysis buffer were denatured for $2 \mathrm{~min}$ at $37^{\circ} \mathrm{C}$ followed by a $5 \mathrm{~min}$ incubation at $4^{\circ} \mathrm{C}$. Reverse transcription (RT) was performed as previously described (Gibson et al., 2009) with slight modifications. RT reagents were added to each sample [0.1 $\mu$ l dNTP's ( $25 \mathrm{~mm}$; Thermo Fisher Scientific), $0.25 \mu \mathrm{l}$ MMLV Reverse Transcriptase (Promega), $1 \mu \mathrm{l}$ MMLV $5 \times$ buffer, $0.6 \mu \mathrm{l}$ $\mathrm{MgCl}_{2}, 0.05 \mu \mathrm{l}$ Rnasin plus (Promega), and $0.5 \mu \mathrm{l}$ water], and reactions were incubated at cycling temperatures $\left(37^{\circ} \mathrm{C} 2 \mathrm{~min}, 42^{\circ} \mathrm{C} 1 \mathrm{~min}, 50^{\circ} \mathrm{C} 1 \mathrm{~s}\right.$ for 40 cycles, then $85^{\circ} \mathrm{C} 5 \mathrm{~min}$, and $4^{\circ} \mathrm{C}$ hold). Preamplification reactions consisted of $2 \mu \mathrm{l} \mathrm{cDNA}$ (from previous RT), $2.5 \mu \mathrm{l} 0.2$ TaqMan pooled assay, $5 \mu \mathrm{l}$ Takara Premix TaqDNA Polymerase (Clontech), and $0.5 \mu \mathrm{l}$ water. Reactions were amplified: $95^{\circ} \mathrm{C} 3 \mathrm{~min}, 55^{\circ} \mathrm{C} 2 \mathrm{~min}, 72^{\circ} \mathrm{C} 2 \mathrm{~min}$; then $95^{\circ} \mathrm{C} 15 \mathrm{~s}, 60^{\circ} \mathrm{C} 2 \mathrm{~min}, 72^{\circ} \mathrm{C} 2 \mathrm{~min}$ for 16 cycles followed by a $4^{\circ} \mathrm{C}$ hold.

Neuroblasts were isolated from unbiased single-cell preparations following prescreening for Dcx expression via qPCR using preamplified cDNA and the TaqMan gene expression assay for Dcx (Mm00438400_m1) according to the manufacturer's instructions. $\mathrm{Dcx}^{+}$cells and cells sorted for tdTomato fluorescence were subjected to further analysis using the Flex Six Gene Expression Integrated Fluidic Circuit (Fluidigm) on the Biomark HD platform according to the manufacturer's instructions, using the following TaqMan gene expression assays: Dcx (Mm00438400_m1), Gfap (Mm01253033_m1), Pecam 1 (Mm01242584_m1), Aif1 (Mm00479862_g1), Aldh1l1 (Mm0304 8957_m1), Aqp4 (Mm00802131_m1), Gapdh (Mm99999915_g1), EPHA4 (Mm00433056_m1), EFNA1 (Mm01212795_m1), EFNA2 (Mm00433 011_m1),EFNA3 (Mm01212723_g1),EFNA4(Mm00433013_m1), EFNA5 (Mm01237700_m1), EFNB1 (Mm00438666_m1), EFNB2 (Mm00438 670_m1), and EFNB3 (Mm00433016_m1). Gene expression data were an- 
alyzed using the Fluidigm Real-Time PCR Analysis software and gplots package in R.

\section{Results}

EphA4 is critical for organization of neuroblasts in the adult SVZ and RMS To investigate EphA4's functional role in the SVZ, we examined whole-mount preparations of the anterior lateral ventricle wall from adult EphA4 ${ }^{+/+}$wildtype $\left(E p h A 4^{+/+}\right)$and null mutant EphA $4^{-/-}$mice. Typically, $\mathrm{Dcx}^{+}$neuroblasts within the SVZ formed tightly fasciculated chains oriented parallel to one another in arrayed bundles (Fig. 1A);

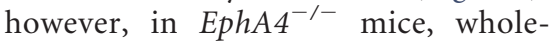
mount preparations of the anterior lateral ventricle wall showed disorganized neuroblasts that lacked ordered, parallel alignment and bundling. This disorganization and lack of bundling along the SVZ resulted in diffuse DCx labeling when the lateral ventricle wall was viewed en face (Fig. 1A). Diffuse Dcx labeling correlated with the absence of parallel alignment and fasciculation of chains resulting in easily observable immunolabeling; $\mathrm{Dcx}^{+}$neuroblasts were not reduced, just not properly aligned.

Transmission electron microscopy (TEM) of the anterior forebrain of EphA4 ${ }^{+/+}$mice, used to examine the cytoarchitecture of the SVZ, showed the typical monolayer of ependymal cells along the length of the lateral ventricle wall and an underlying SVZ stem cell niche of neuroblast clusters surrounded by astrocytes and a scattering of transit amplifying progenitors (Fig. $1 B)$. In contrast, TEM of the anterior forebrain of EphA4 $4^{-1-}$ mice revealed that neuroblasts were more dispersed and many breached SVZ boundaries and populated the corpus callosum (Fig. 1B). This atypical distribution of neuroblasts was corroborated by immunolabeling of coronal sections of the SVZ and neighboring structures, where $\mathrm{Dcx}^{+}$neuroblasts were found in both the striatum (Fig. 1C) and corpus callosum (Fig. 1D). Together, these findings indicate that EphA4 functions in neuroblast bundling, orientation, and confinement to establish SVZ boundaries.

We then assessed the functional importance of EphA4-ephrin signaling in the RMS. Eph-ephrin interactions can result in three possible outcomes: classical "forward" signaling through the Eph receptor, "reverse" signaling through ephrin ligands, or a combination of both resulting in bidirectional signaling (Fig. $2 A)$. We examined anterior forebrain coronal sections from adult EphA4 ${ }^{-/-}$ mice, in which both forward and reverse
A

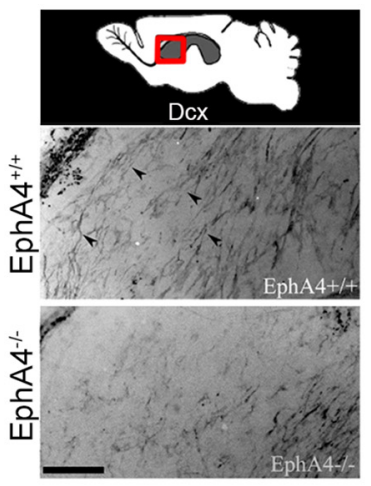

B

EphA4 ${ }^{+/+}$

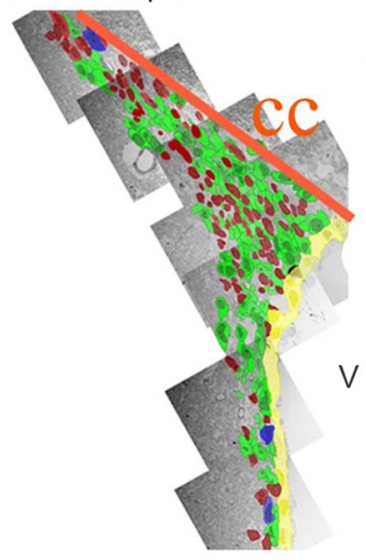

$\square$ Ependymal cell Astrocyte

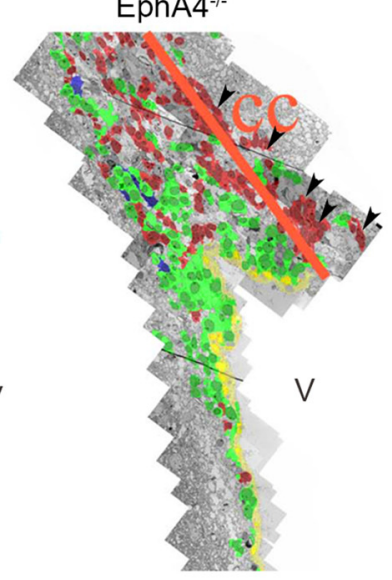

EphA4

$\square$ Neuroblast

$\square$ TAP cell
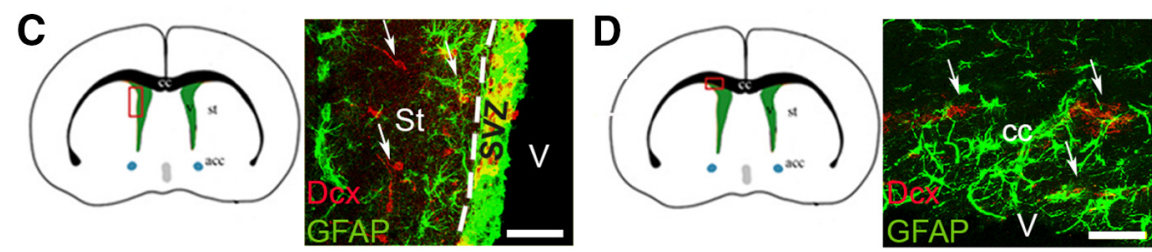

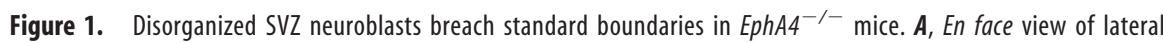
ventricle wall whole mounts from EphA4 $4^{+/+}$and $E p h A 4^{-/-}$adult mice. Top, Region of whole-mount preparations. Black arrowheads indicate neuroblast chains. B, TEM montages of the SVZ and adjacent corpus callosum (cc) of EphA4 ${ }^{+/+}$and $E p h A 4^{-/-}$adult mice. Orange line indicates boundary between $c c$ and SVZ. Black arrowheads indicate neuroblasts that have breached standard SVZ boundaries. $\boldsymbol{C}, \boldsymbol{D}$, Immunohistochemistry confirms the presence of $D \mathrm{Cx}^{+}$(red) neuroblasts (white arrows) in neighboring striatum (St) and cc. Green represents GFAP ${ }^{+}$astrocytes. Schematics indicate regions depicted in $\boldsymbol{C}, \boldsymbol{D}$. V, Ventricular space. Scale bars: $\boldsymbol{A}, 100 \mu \mathrm{m} ; \boldsymbol{C}, \boldsymbol{D}, 50 \mu \mathrm{m}$.
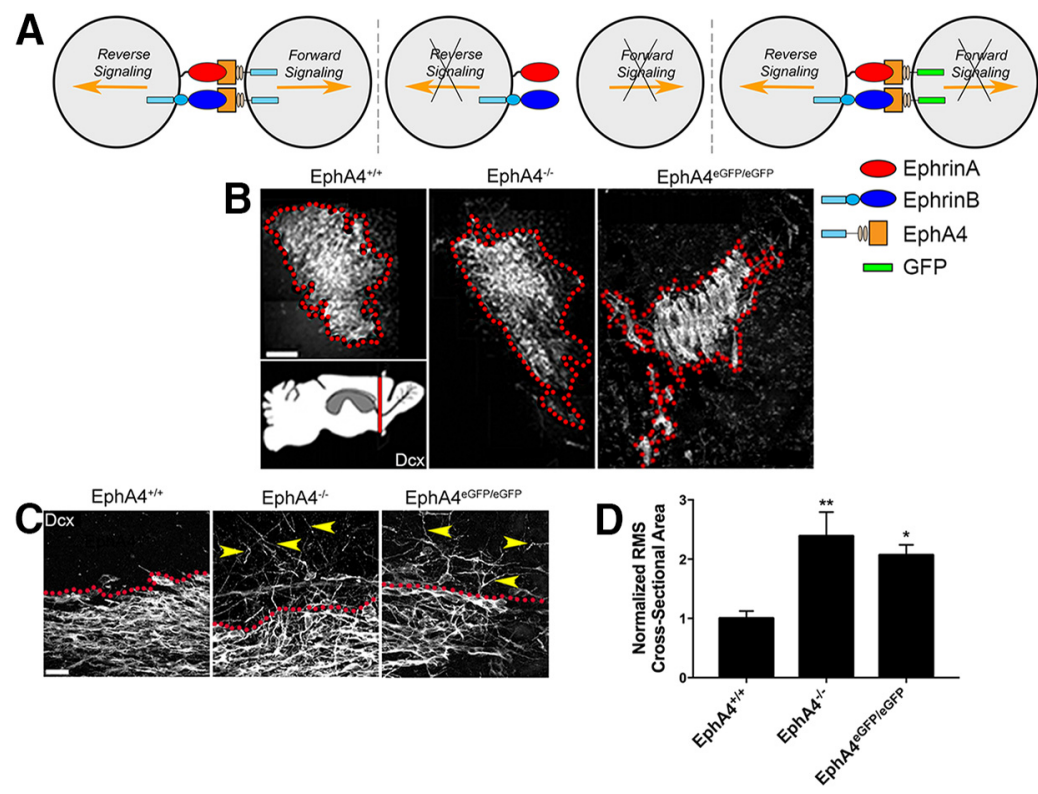

Figure 2. EphA4 forward signaling is required to organize migrating neuroblasts into a compact, cell-dense adult RMS. $A$, Schematic of EphA4 forward, reverse, and bidirectional signaling in EphA4 ${ }^{+/+}, E p h A 4^{-1-}$, and KD-EphA4 ${ }^{\text {eGFP/eGFP }}$ adult mice. $\boldsymbol{B}$, Representative coronal sections of mature RMS neuroblasts (Dcx-immunolabeled) proximal to the lateral ventricle from $\mathrm{EphA4}^{+/+}, \mathrm{EphA4}^{-/-}$, and KD-EphA4${ }^{\text {eGFP/eGFP }}$ mice. Bottom left, Region where coronal sections were isolated. C, Representative sagittal sections of mature RMS neuroblasts from EphA4 ${ }^{+/+}, E p h A 4^{-/-}$, and KD-EphA4 $4^{\text {eGFP/eGFP }}$ mice. Yellow arrowheads indicate neuroblasts migrating outside of the standard RMS trajectory. D, Quantification of RMS cross-sectional areas from EphA4 ${ }^{+/+}$, EphA4 $^{-1-}$, and KD-EphA4 $4^{\text {eGFPleGFP }}$ adult mice. ${ }^{*} p<0.05 .{ }^{* *} p<0.01$. Error bars indicate SEM. Scale bars: $B, 100 \mu \mathrm{m} ; \boldsymbol{C}, 20 \mu \mathrm{m}$. 

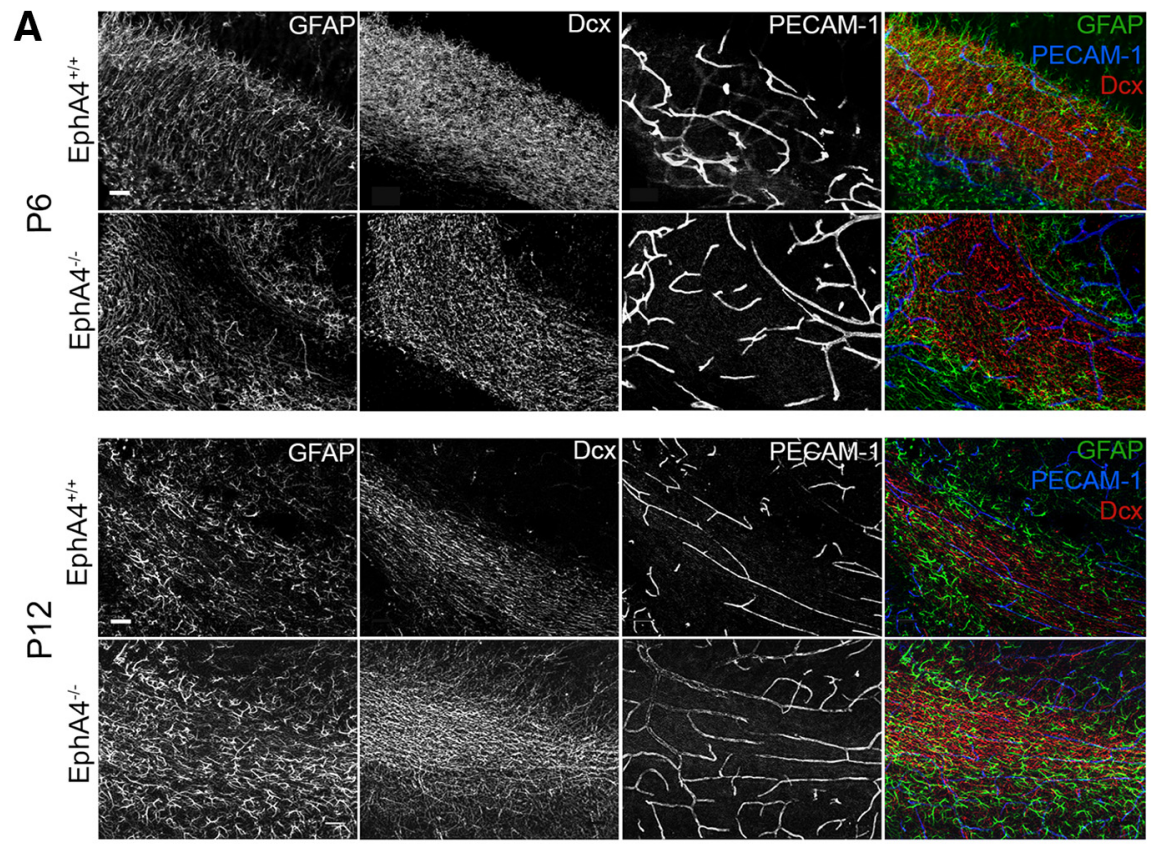

B

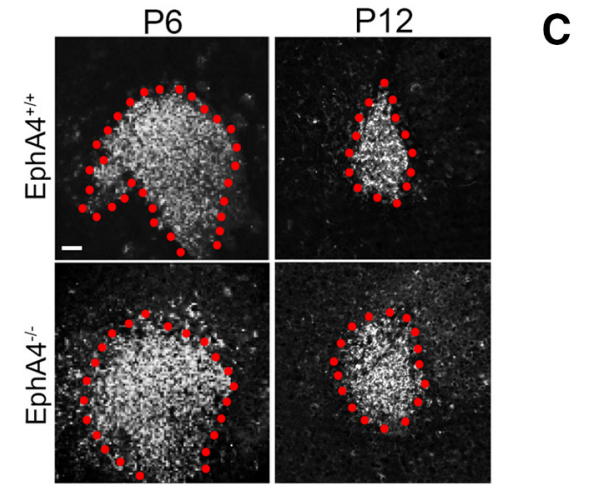

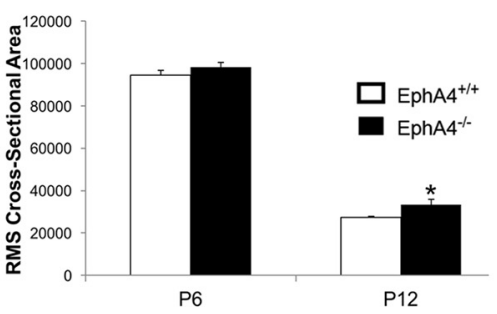

Figure 3. EphA4 acts during postnatal development to condense neuroblasts within what is to become the mature RMS. $\boldsymbol{A}$, Representative sagittal sections of the RMS showing organization of astrocytes (GFAP; green), neuroblasts (Dcx; red), and vasculature (PECAM-1; blue) in EphA4 ${ }^{+/+}$and EphA4 ${ }^{-/-}$mice at P6 and P12. B, Representative coronal sections of RMS neuroblasts (Dcx immunolabeled) from EphA4 ${ }^{+/+}$and EphA4 ${ }^{-/-}$mice at postnatal day (P) 6 and P12. Scale bar, $50 \mu \mathrm{m}$. C, Quantification of RMS areas in P6 and P12 EphA4 ${ }^{+/+}$and EphA4 $4^{-/-}$mice. ${ }^{*} p<0.05$. Error bars indicate SEM. Scale bar, $50 \mu \mathrm{m}$.

During the early stages of this process (up to and including postnatal day 3), the RMS consists solely of loosely associated neuroblasts, which migrate en masse toward the OB (Nie et al., 2010). By P6, astrocytes begin to infiltrate the RMS core; and by P12, a complex meshwork of astrocytes exists within the RMS (Peretto et al., 2005). To determine when EphA4-ephrin interactions become necessary, we examined the organization of RMS neuroblasts in sagittal and coronal sections at P6 and P12 (Fig. 3). Representative sagittal images of the RMS (Fig. 3A) at P6 show that GFAP ${ }^{+}$astrocytes are beginning to enter the RMS core in both $\mathrm{EphA}^{+/+}$and EphA4${ }^{-/-}$mice. At P12, astrocytes in EphA $4^{+/+}$mice are oriented parallel to migrating neuroblasts, whereas astrocytes in EphA4 ${ }^{-/-}$mice lack directionality and are disorganized and hypertrophic.

$\mathrm{Dcx}^{+}$neuroblasts at P6 (before astrocyte invasion) show a similar loose organization in EphA4 $4^{+/+}$and EphA4 $4^{-/-}$mice when viewed in sagittal (Fig. $3 A$ ) and coronal section (Fig. 3B), with no significant difference in relative RMS cross-sectional area (Fig. $3 C)$. By P12 when the RMS begins to compact, the core of neuroblasts is more loosely arranged and exhibits a larger cross-sectional in the RMS of EphA4 ${ }^{-/-}$mice compared with EphA4 $4^{+/+}$mice (Fig. $3 A-C$ ), with many neuroblasts exhibiting radial migration perpendicular to the normal direction of tangential chain migration (Fig. 3A). PECAM-1 immunolabeling of endothelial cells revealed that RMS blood vessels do not display any organizational differences in P6 or P12 between the EphA4 ${ }^{+/+}$and EphA4 ${ }^{-/-}$ mice (Fig. $3 A$ ). Together, our data suggest that, as the RMS develops from a loose array of tangentially migrating neuroblasts to a more condensed structure of

signaling was ablated, and KD-EphA4 $4^{e G F P / e G F P}$ mice (Kullander et al., 2001) in which only forward signaling was blocked. The RMS is typically characterized by dense, parallel bundles of migratory $\mathrm{Dcx}^{+}$neuroblasts that transit through the anterior forebrain $\left(E p h A 4^{+/+}\right.$mice; Fig. 2B,C). In $E p h A 4^{-/-}$and $K D$-EphA4 $4^{e G F P / e G F P}$ mice, $\mathrm{Dcx}^{+}$neuroblasts were more loosely organized, with many orientated perpendicular to the RMS when viewed in both cross and sagittal section (Fig. $2 B, C)$. Area measurements taken along the length of the RMS confirmed that both EphA4 $4^{-/-}$and KD-EphA4 $4^{e G F / e G F P}$ mice had significantly larger average cross-sectional areas compared with EphA4 ${ }^{+/+}$mice (Fig. 2D). These findings confirm that EphA4 forward signaling is critical for proper alignment of neuroblast migration tangential to the lateral ventricles and for the overall compactness of the RMS.

\section{EphA4 initiates mature RMS organization in late} postnatal development

Organization of the postnatal rodent RMS into the mature adult RMS occurs from birth until $\sim 21 \mathrm{~d}$ of age (Peretto et al., 2005). fasciculated neuroblast chains surrounded by an astroglial meshwork, EphA4 signaling becomes critical for restriction and containment of neuroblasts and organization of astrocytes within a narrow RMS corridor, as found in the late postnatal and mature adult anterior forebrain.

\section{EphA4 is also required for organization of the adult RMS astroglial meshwork}

Our finding that EphA4 is essential for astrocyte organization in the developing RMS prompted us to investigate the role of EphA4, and more specifically EphA4 forward signaling, in adult RMS astrocytes. The RMS astroglial meshwork consists of a dense grouping of astrocytes with elongated, bipolar morphology and an orientation parallel to chains of migrating neuroblasts (EphA4 ${ }^{+/+}$; Fig. 4). Similar to the disorganization of RMS neuroblasts in adult EphA4${ }^{-/-}$mice (Fig. 2), RMS astrocytes were significantly disorganized and the cell bodies appeared hypertrophic in the absence of EphA4 (Fig. 4). In many cases, astrocytic processes lacked parallel projection alignment and displayed a tangled appearance (Fig. 4, red arrowheads). The astrocyte disorganization was pheno- 
typically mimicked in KD-EphA4 $4^{e G F P / e G F P}$ mice, indicating that EphA4 exerts its effects on astrocyte organization via forward signaling. These findings suggest that either neuroblast-astrocyte heterotypic EphA4 signaling or astrocyte-astrocyte homotypic EphA4 interactions would appear to be required for RMS astroglial meshwork organization.

\section{Absence of EphA4 delays neuroblast integration within the $\mathrm{OB}$}

Based on the above findings showing neuroblast and astrocyte disorganization in EphA4 ${ }^{-/-}$mice, we next examined whether EphA4 absence affected the efficiency of neuroblast migration to the $\mathrm{OB}$ and in particular to the PGL. We administered the thymidine analog EdU and analyzed the number of EdU ${ }^{+}$cells that remained in the SVZ or had migrated to the RMS or OB $21 \mathrm{~d}$ later. Twenty-one days allows sufficient time for newly formed neuroblasts to migrate from the SVZ along the RMS and to integrate within the existing $\mathrm{OB}$ circuitry (Luskin, 1993; Lois et al., 1996). We found no difference in the total number of $\mathrm{EdU}^{+}$ cells in the SVZ of EphA4 ${ }^{+/+}$and EphA4 ${ }^{-/-}$ mice 21 days after injection (Fig. $5 A$ ), indicating that labeled neuroblasts had left the SVZ and that only slow-cycling SVZ neural stem and progenitor cells remained (Codega et al., 2014; Zhang et al., 2015). However, evaluation of the total number of $\mathrm{EdU}^{+}$cells that reached the $\mathrm{OB}$ in EphA4 $4^{-/-}$mice revealed a significant decrease in number $(\sim 22 \%)$, with an even more dramatic decrease in the number of $\mathrm{EdU}^{+}$cells integrating into the PGL $(\sim 49 \%)$ compared with EphA4 ${ }^{+/+}$mice (Fig. $5 A, B$ ). These findings indicate that EphA4 is required for the efficient transit of neuroblasts to their final site of differentiation in the $\mathrm{OB}$.

To assess whether there were any differences in proliferation or cell cycle dynamics, we examined the percentage of $\mathrm{BrdU}^{+}$cells out of the total population of $\mathrm{Ki}^{+} 7^{+}$cells in

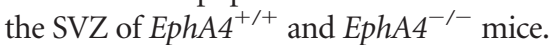
We found no difference, indicating that cell cycle dynamics were similar in EphA4 ${ }^{+/+}$ and EphA $4^{-/-}$SVZ (Fig. 5C). Additionally, we found no significant differences in the number of caspase- $3^{+}$cells in the SVZ, RMS, and $\mathrm{OB}$ of EphA4 ${ }^{+/+}$and EphA4 ${ }^{-/-}$ mice, indicating no differences in cell death levels (Fig. 5D).

RMS neuroblasts and astrocytes show cell-specific mosaic expression of EPHA4 and EFN transcripts

The above findings indicate that EphA4 is required for the organization of both
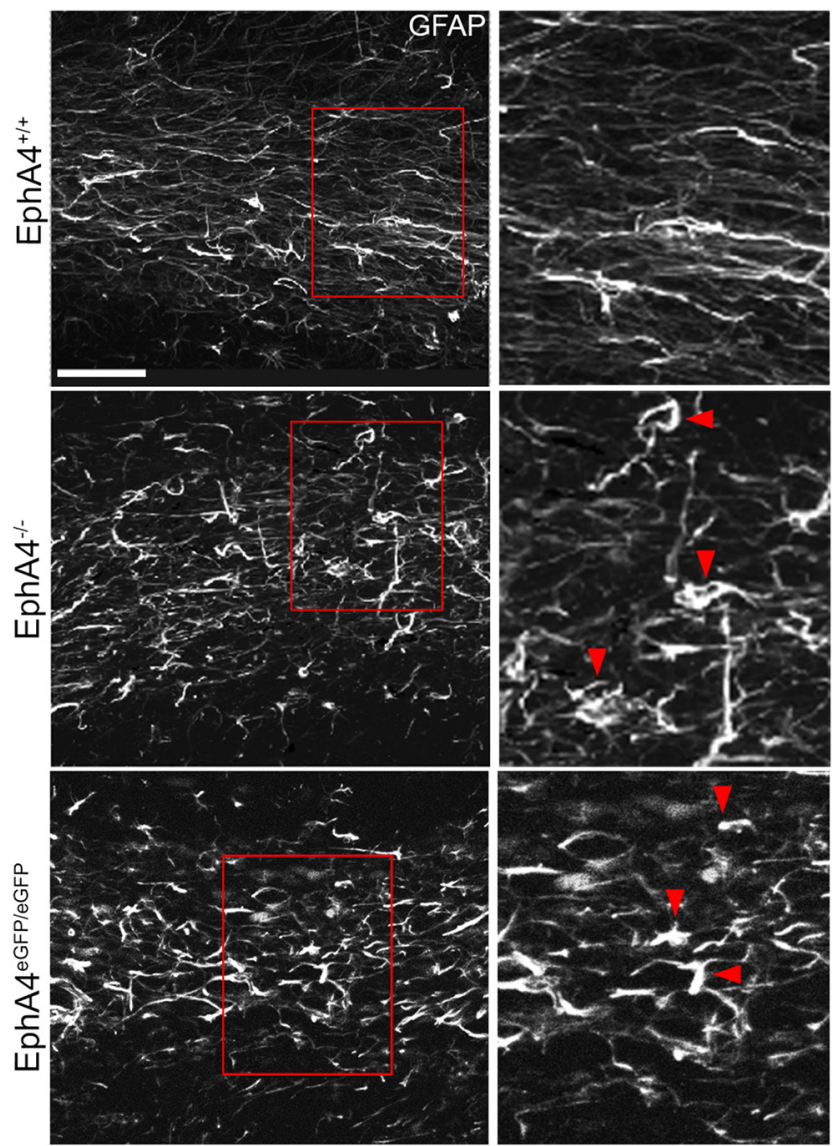

Figure 4. Astroglial meshwork morphology is disorganized in the RMS of adult EphA4 ${ }^{-/-}$and KD-EphA ${ }^{\text {eGFP/eGFP }}$ mice. Representative sagittal sections of RMS astrocytes (GFAP-immunolabeled) from EphA4 ${ }^{+/+}$, EphA4 ${ }^{-1-}$, and KD-EphA4 ${ }^{\text {eGFP/eGFP }}$ mice. Right, To better portray cell morphology, red boxed regions represent "zoomed-in" images. Red arrowheads indicate astrocytes exhibiting hypertrophy and/or abnormal organization. Scale bar, $200 \mu \mathrm{m}$.
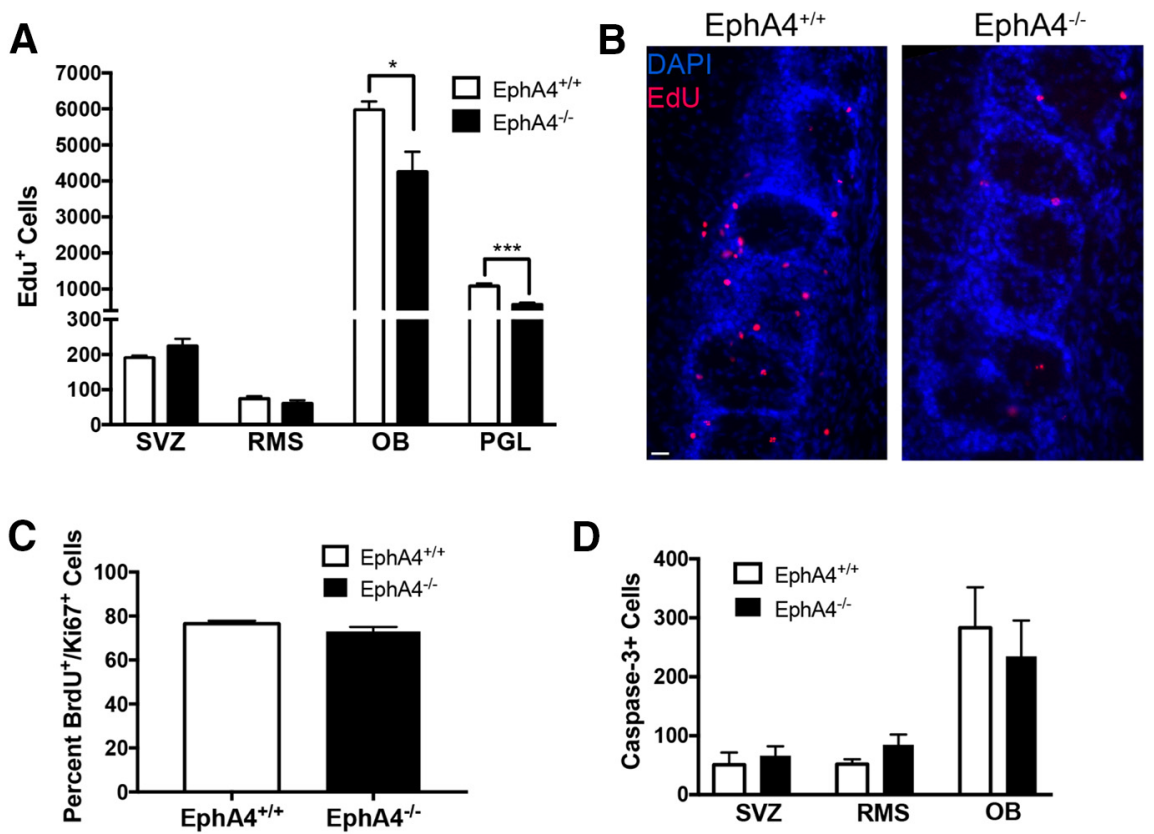

Figure 5. EphA4 is needed for directed neuroblast migration to the $O B$ and integration into the PGL. $\boldsymbol{A}$, Representative images of EdU ${ }^{+}$cells in the PGL of OB from EphA4 ${ }^{+/+}$and EphA4 ${ }^{-/-}$mice. $B$, Total number of EdU ${ }^{+}$cells in the SVZ, RMS, $O B$, and PGL of EphA4 ${ }^{+/+}$and EphA4 ${ }^{-/-}$mice. C, Percentage BrdU ${ }^{+} / \mathrm{Ki} 7^{+}$cells in the SVZ of EphA4 ${ }^{+/+}$and EphA4 ${ }^{-/-}$ mice. D, Number of caspase- $3^{+}$cells in the SVZ, RMS, and OB of EphA4 ${ }^{+/+}$and EphA4 ${ }^{-/-}$mice. ${ }^{*} p<0.05$. ${ }^{* *} p<$ 0.001. Error bars indicate SEM. Scale bar, $25 \mu \mathrm{m}$. 


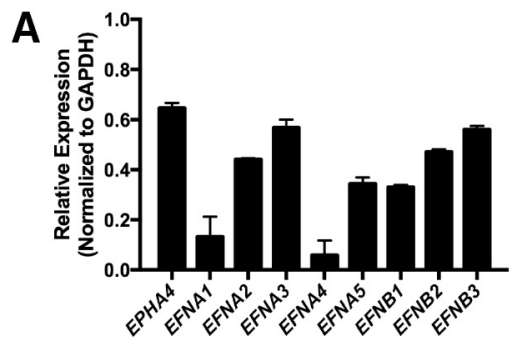

\begin{tabular}{|c|c|c|c|}
\hline Comparison & Sig. & Comparison & Sig. \\
\hline EPHA4 vs. EFNA1 & $* * *$ & EPHA4 vs. EFNA1 & ns \\
\hline EPHA4 vs. EFNA2 & $* *$ & EPHA4 vs. EFNA2 & ns \\
\hline EPHA4 vs. EFNA3 & ns & EPHA4 vs. EFNA3 & ns \\
\hline EPHA4 vs. EFNA4 & $* * *$ & EPHA4 vs. EFNA4 & $* * *$ \\
\hline EPHA4 vs. EFNA5 & $* * *$ & EPHA4 vs. EFNA5 & $* *$ \\
\hline EPHA4 vs. EFNB1 & $* * *$ & EPHA4 vs. EFNB1 & $* *$ \\
\hline EPHA4 vs. EFNB2 & $*$ & EPHA4 vs. EFNB2 & ns \\
\hline EPHA4 vs. EFNB3 & ns & EPHA4 vs. EFNB3 & ns \\
\hline EFNA1 vs. EFNA2 & $* * *$ & EFNA1 vs. EFNA2 & $* * *$ \\
\hline EFNA1 vs. EFNA3 & $* * *$ & EFNA1 vs. EFNA3 & $* * *$ \\
\hline EFNA1 vs. EFNA4 & ns & EFNA1 vs. EFNA4 & $* * *$ \\
\hline EFNA1 vs. EFNA5 & $*$ & EFNA1 vs. EFNA5 & $* * *$ \\
\hline EFNA1 vs. EFNB1 & $*$ & EFNA1 vs. EFNB1 & ns \\
\hline EFNA1 vs. EFNB2 & $* * *$ & EFNA1 vs. EFNB2 & ns \\
\hline EFNA1 vs. EFNB3 & $* * *$ & EFNA1 vs. EFNB3 & $* *$ \\
\hline EFNA2 vs. EFNA3 & ns & EFNA2 vs. EFNA3 & ns \\
\hline EFNA2 vs. EFNA4 & $* * *$ & EFNA2 vs. EFNA4 & $* *$ \\
\hline EFNA2 vs. EFNA5 & ns & EFNA2 vs. EFNA5 & ns \\
\hline
\end{tabular}

B
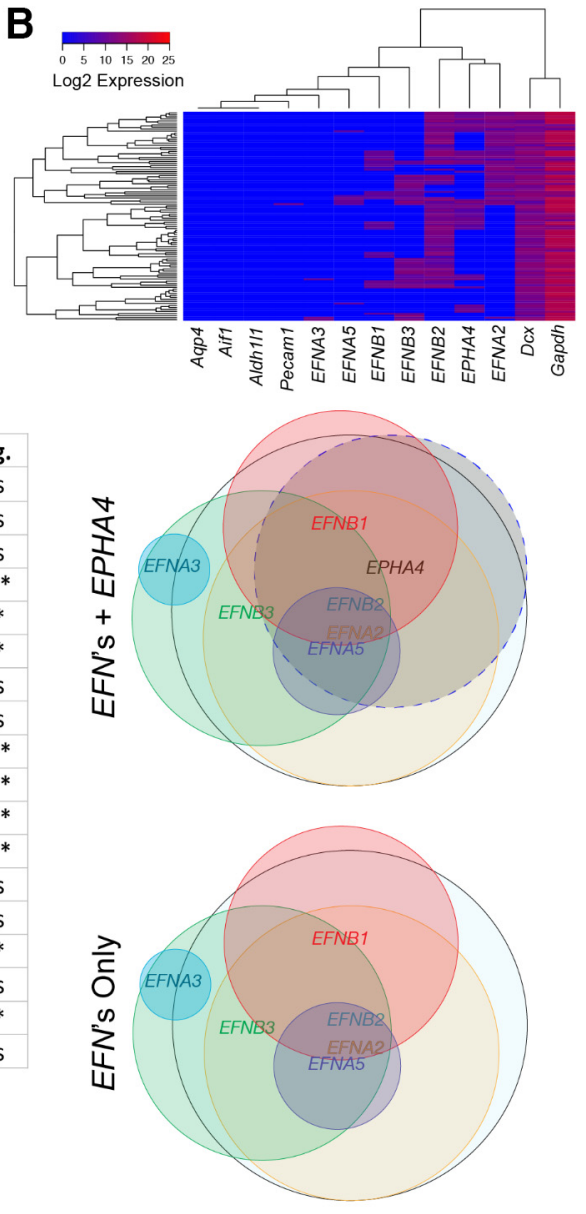
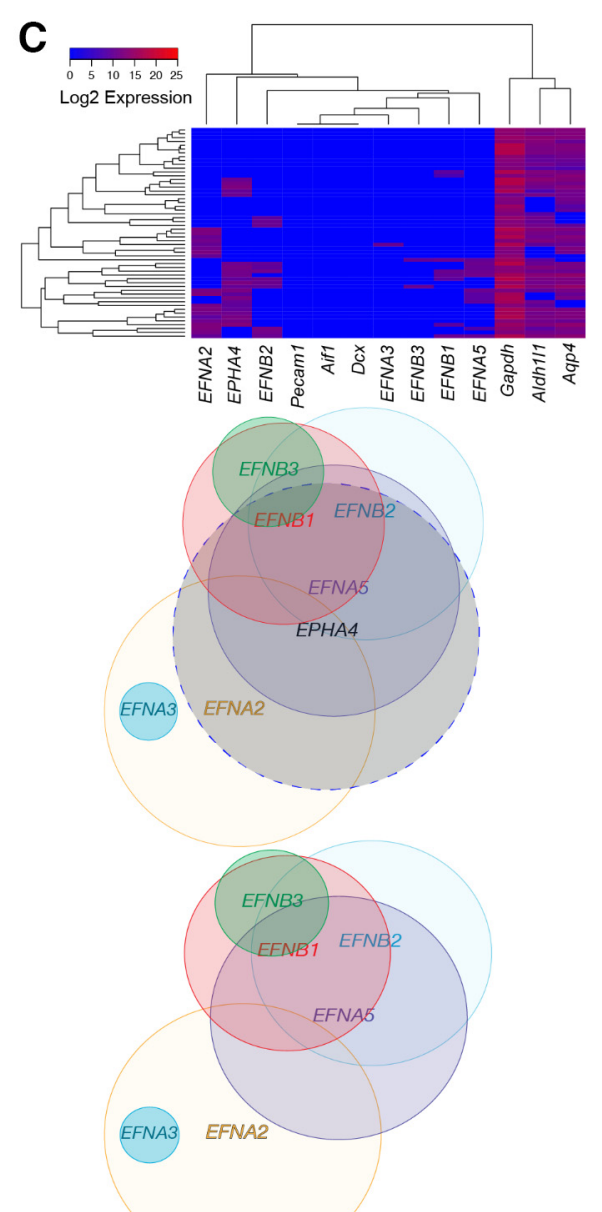

Figure 6. RMS neuroblasts and astrocytes display a mosaic expression of EPHA4 and EFN genes. $A$, qPCR of total RMS lysates. All expression values are displayed as inverse $C_{t}$ normalized to Gapdh expression. Bottom, Statistical analysis of relative expression. ${ }^{*} p<0.05 .{ }^{* *} p<0.01$. ${ }^{* * *} p<0.001$. Error bars indicate SEM. $B, C$, Heatmaps of single-cell gene expression (hierarchical clustering) for EPHA4, EFNA2, EFNA3, EFNA5, EFNB1, EFNB2, and EFNB3 in RMS neuroblasts $(\boldsymbol{B})$ and RMS astrocytes (C). All expression values are displayed as inverse $C_{\text {t }}$. Euler diagrams below each heat map represent gene coexpression in the respective cell type. For ease of interpretation, the Euler diagrams are shown with (top) and without (bottom) EPHA4.

neuroblasts and astrocytes in the SVZ and RMS. Although neuroblasts still reach the $\mathrm{OB}$ in the absence of EphA4, there is a marked decrease in the overall number of neuroblasts integrating into the $\mathrm{OB}$ and specifically the GL. To examine cellspecific expression patterns and to define potential cell-cell interactions between EphA4 and its ephrin-binding partners, we initially analyzed total RMS lysate (control mice) for transcripts. This analysis revealed robust expression of EPHA4, EFNA2, EFNA3, EFNA5, EFNB1, EFNB2, and EFNB3 genes (Fig. 6A). To delineate cell-specific EPHA4/EFN expression, we examined gene expression at the single-cell level. Isolation of single neuroblasts was validated by expression of Gapdh and $D c x$ in the absence of Pecam1 (platelet endothelial adhesion molecule 1; endothelial cells), Aif1 (allograft inflammatory factor 1; microglia), Aqp4 (aquaporin 4; astrocytes), and Aldh 111 (aldehyde dehydrogenase 1 family, member L1; astrocytes) (Fig. 6B). EPHA4 was expressed in $39.8 \%$ of neuroblasts. The most frequently expressed $E F N$ in neuroblasts was EFNB2 (75.7\%) followed by EFNA2 (45.6\%), EFNB3 (35\%), EFNB1 (25.2\%), EFNA5 (6.8\%), and EFNA3 (2.9\%). The most frequently coexpressed EFNs were EFNA2 and EFNB2 (35.9\%), and EPHA4 was most often coexpressed with EFNB2 (35\%) followed by EFNA2 (20.4\%). In total, $89.3 \%$ of neuroblasts expressed at least one EFN, and $93.2 \%$ of neuroblasts expressed EPHA4, EFN(s), or a combination thereof. Total percentages of EPHA4/EFN expression and coexpression in neuroblasts are shown in Table 1. Euler diagrams, positioned below the heat map, show relative gene expression and coexpression of EFN genes with one another and with EPHA4 in neuroblasts (Fig. 6B).

In a similar experiment, we isolated single astrocytes and found that EPHA4 was expressed in 40\% of all SVZ/RMS astrocytes (Fig. 6C). EFNs were present at a lower frequency in astrocytes $(62 \%)$ than in neuroblasts $(89.3 \%)$, and the most abundant ligand was EFNA2 (34.5\%) followed by EFNB2 (21.8\%), EFNA5 (20\%), EFNB1 (14.54\%), EFNB3 (3.6\%), and EFNA3 (1.8\%). The most commonly coexpressed EFNs were EFNA2 (14.5\%) and EFNA5 (14.5\%), and the most commonly coexpressed with EPHA4 was EFNA2. In total, 70.9\% of astrocytes express EPHA4, EFN(s), or both. Total percentages of EPHA4/EFN expression and coexpression in astrocytes are shown in Table 1. Euler diagrams show relative gene expression and coexpression of EFN genes with one another and with EPHA4 in astrocytes

(Fig. 6C).

The complex gene expression patterns of EphA4 and its ephrin binding partners were confirmed at the protein level in Figure 7. EphA4 was expressed by approximately half of RMS 
Table 1. Expression and coexpression of EPHA4 and EFN genes in RMS neuroblasts and astrocytes ${ }^{a}$

\begin{tabular}{|c|c|c|c|}
\hline \multicolumn{2}{|l|}{ Neuroblasts } & \multicolumn{2}{|l|}{ Astrocytes } \\
\hline Gene(s) & $\begin{array}{l}\% \text { expression or } \\
\text { coexpression }\end{array}$ & Gene(s) & $\begin{array}{l}\text { \% expression or } \\
\text { coexpression }\end{array}$ \\
\hline EPHA4 & 39.81 & EPHA4 & 40.00 \\
\hline EFNA2 & 45.63 & EFNA2 & 34.55 \\
\hline EFNA3 & 2.91 & EFNA3 & 1.82 \\
\hline EFNA5 & 6.80 & EFNA5 & 20.00 \\
\hline EFNB1 & 25.24 & EFNB1 & 14.55 \\
\hline EFNB2 & 75.73 & EFNB2 & 21.82 \\
\hline EFNB3 & 34.95 & EFNB3 & 3.64 \\
\hline EPHA4, EFNA2 & 20.39 & EPHA4, EFNA2 & 14.55 \\
\hline EPHA4, EFNA3 & 0.97 & EPHA4, EFNA3 & 0.00 \\
\hline EPHA4, EFNA5 & 3.88 & EPHA4, EFNA5 & 14.55 \\
\hline EPHA4, EFNB1 & 11.65 & EPHA4, EFNB1 & 7.27 \\
\hline EPHA4, EFNB2 & 34.95 & EPHA4, EFNB2 & 10.91 \\
\hline EPHA4, EFNB3 & 8.74 & EPHA4, EFNB3 & 1.82 \\
\hline EFNA2, EFNA3 & 0.97 & EFNA2, EFNA3 & 1.82 \\
\hline EFNA2, EFNA5 & 5.83 & EFNA2, EFNA5 & 7.27 \\
\hline EFNA2, EFNB1 & 13.59 & EFNA2, EFNB1 & 3.64 \\
\hline EFNA2, EFNB2 & 35.92 & EFNA2, EFNB2 & 5.45 \\
\hline EFNA2, EFNB3 & 17.48 & EFNA2, EFNB3 & 0.00 \\
\hline EFNA3, EFNA5 & 0.00 & EFNA3, EFNA5 & 0.00 \\
\hline EFNA3, EFNB1 & 0.00 & EFNA3, EFNB1 & 0.00 \\
\hline EFNA3, EFNB2 & 0.97 & EFNA3, EFNB2 & 0.00 \\
\hline EFNA3, EFNB3 & 2.91 & EFNA3, EFNB3 & 0.00 \\
\hline EFNA5, EFNB1 & 1.94 & EFNA5, EFNB1 & 7.27 \\
\hline EFNA5, EFNB2 & 4.85 & EFNA5, EFNB2 & 9.09 \\
\hline EFNA5, EFNB3 & 4.85 & EFNA5, EFNB3 & 1.82 \\
\hline EFNB1, EFNB2 & 20.39 & EFNB1, EFNB2 & 5.45 \\
\hline EFNB1, EFNB3 & 10.68 & EFNB1, EFNB3 & 1.82 \\
\hline EFNB2, EFNB3 & 26.21 & EFNB2, EFNB3 & 1.82 \\
\hline
\end{tabular}

${ }^{a}$ Values are percentage expression of EPHA4, each EFN, or combinations thereof in single RMS neuroblasts and astrocytes.

$\mathrm{Dcx}^{+}$neuroblasts, and colocalized with multiple $\mathrm{GFAP}^{+}$RMS astrocytes (yellow arrowheads). EphrinA2 was also expressed on approximately half of neuroblasts and, to a lesser degree, on astrocytes. In agreement with gene expression data, the ephrinB ligands were expressed on a majority of neuroblasts and a smaller fraction of astrocytes.

\section{Discussion}

The long-distance migration of newly generated SVZ neuroblasts along the RMS, and through mature forebrain structures, to the granule and periglomerular layers of the $\mathrm{OB}$ necessitates directed and tightly constrained navigation. To achieve this, neuroblasts use a unique method of transit in which they travel along each other as tightly fasciculated chains within a surrounding astroglial meshwork (Belvindrah et al., 2007; Kaneko et al., 2010). We found that forward signaling through the tyrosine kinase receptor EphA4 is essential for the formation of compact, aligned neuroblast bundles within an SVZ/RMS astroglial meshwork, an organization that facilitates neuroblast transit through the anterior forebrain. Forward signaling through EphA4 is known to be involved in downstream alterations in actin filament dynamics leading to axonal growth cone collapse and repulsion, events integral to proper axonal guidance (Shamah et al., 2001; Sahin et al., 2005). EphA4-ephrin signaling can alter cytoskeletal arrangement directly or with the help of effector proteins, including ephexins, leading to the formation of cell-cell and cell-matrix focal adhesions and migration (Puschmann and Turnley, 2010). Interestingly, it was recently shown that forward signaling through Eph receptors is necessary and sufficient for the Rho kinase-dependent generation of an actin differential that drives adhesive/repulsive signaling events leading to directed movement of embryonic neuroepithelial cells (O’Neill et al., 2016). These studies linking forward signaling through Eph receptors to adhesion and migration, specifically through cytoskeletal modulation, directly support our findings that EphA4 is essential for the maintenance of RMS neuroblast fasciculation and coordinated, directed migration to final sites of differentiation in the OB.

Interestingly, we found that EphA4 is not necessary for RMS organization at P6, a time point when astrocytes are just beginning to infiltrate the RMS. However, by $\mathrm{P} 12$, when the astroglial meshwork in the RMS is forming, the absence of EphA4 resulted in disorganized RMS neuroblasts that did not form fasciculated bundles, as well as misaligned and hypertrophic RMS astrocytes. This resulted in a loosely organized, chaotic RMS (Fig. 8). Our findings suggest that the transition of astrocytes from the RMS perimeter to the RMS core is essential to facilitate neuroblast bundling and alignment to generate the compact, mature adult RMS; this is likely due to heterotypic astrocyte-neuroblast EphA4-mediated interactions.

Single-cell gene expression analysis in the RMS showed, for the first-time, intricate patterns of EphA4 and ligand ephrin expression on discrete subpopulations of both neuroblasts and astrocytes, with coexpression of multiple ligands, receptors, or both within the same cell (Fig. 6). More than $90 \%$ of RMS neuroblasts and $70 \%$ of RMS astrocytes expressed EPHA4, an EFN ligand, or both, pointing toward the importance of Eph-ephrin signaling in this region. EphA4, specifically, was expressed on $40 \%$ of both neuroblast and astrocyte populations, which supports our findings that not all neuroblasts and astrocytes are affected orga-

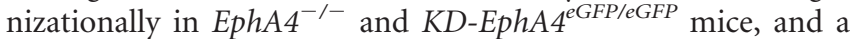
proportion of neuroblasts appear to be unaffected in their transit to the OB in EphA4 $4^{-\prime-}$ mice. Our single-cell studies indicate the heterogeneity of RMS neuroblasts and astrocytes, highlighting the existence of multiple subpopulations that may have discrete functional roles in maintaining neuroblast migration and RMS organization (Merkle et al., 2007; Lledo et al., 2008; GarcíaMarqués et al., 2010). In addition, our results are consistent with studies showing EPH/EFN expression as heterogeneous and complex, with cell-specific, location-specific, and developmentspecific patterns and coexpression patterns involving multiple ligands and/or receptors (Goldshmit et al., 2006; Kania and Klein, 2016). Together, these findings provide a conceptual framework to understand Eph-ephrin interactions in the RMS, in which frequent receptor and ligand expression on neighboring cells or coexpression within the same cell could allow unique and simultaneous forward, reverse, or bidirectional signaling capacities as has been reported in motor axons, the retinotectal system, and in cancer pathogenesis (Marquardt et al., 2005; Dudanova and Klein, 2011; Falivelli et al., 2013). If receptors and ligands are expressed in the same membrane compartment, there is also the potential for cis-interaction on the cell surface, which has been linked to topographic mapping of retinal axons in the tectum (Yin et al., 2004; Carvalho et al., 2006). We suggest that simultaneous activation of multiple Eph-ephrin signaling cascades in subpopulations of cells creates combinatorial signals (neuroblast-neuroblast, astrocyte-astrocyte, neuroblast-astrocyte) that support both attractive and repulsive cues in a uniquely regulated migration pathway for newly generated neuroblasts to transit the mature anterior forebrain.

Eph-ephrin signaling works in concert with other molecular mechanisms that contribute to the dynamic interactions among neuroblasts and astrocytes and are critical for cell migration and 


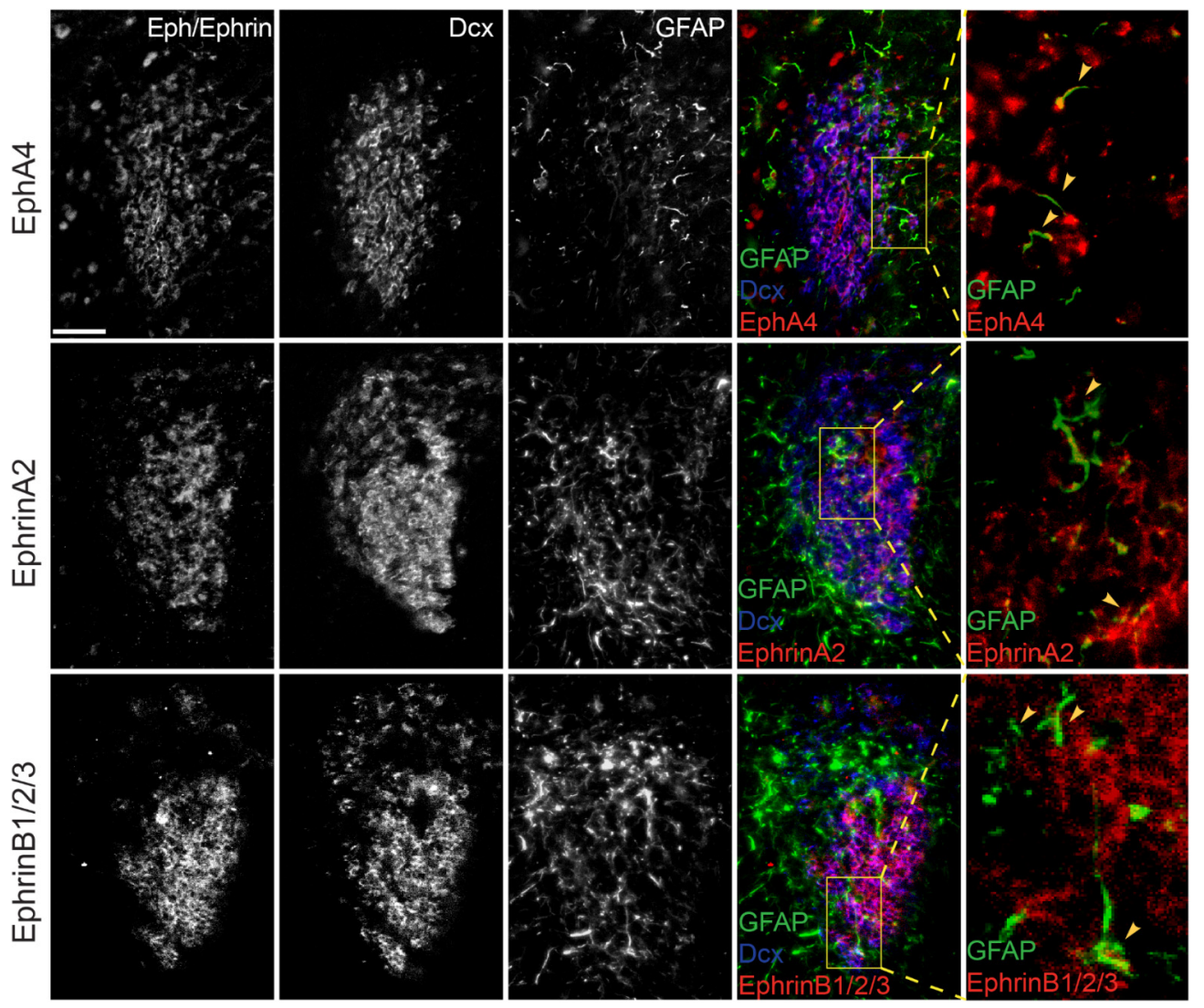

Figure 7. RMS neuroblasts and astrocytes express distinct patterns of EphA4 and ephrin proteins. Coronal sections of the RMS of adult EphA4 ${ }^{+/+}$mice show a unique pattern of EphA4, ephrinA2, and ephrinB expression on neuroblasts and astrocytes. Far right, To better portray Eph/ephrin expression in astrocytes, red boxed regions represent "zoomed-in" images. Green represents GFAP. Blue represents Dcx. Red represents specific EphA4/ephrin immunolabeling. Scale bar, $50 \mu \mathrm{m}$.

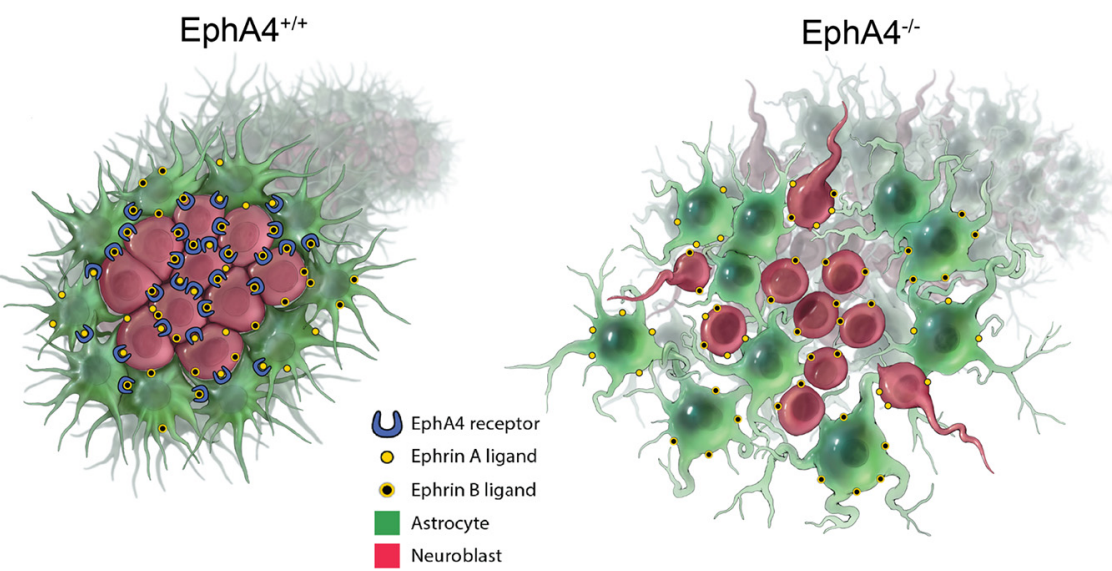

Figure 8. Schematic of EphA4/ephrin expression in the adult EphA4 ${ }^{+/+}$and $E p h A 4^{-/-}$mice. Illustration represents the compact, organized EphA4 ${ }^{-/-}$RMS in contrast to the disorganized and dispersed RMS of EphA4 ${ }^{-/-}$mice. EphA4 and ephrin expression is represented as percentages determined via single-cell transcriptional analysis.

organization within the RMS. RMS neuroblasts secrete Slit1, which associates with transmembrane Robo receptors on neighboring astrocytes and promotes repulsive morphological changes in astrocytes so as to create a pathway for neuroblast migration (Kaneko et al., 2010). The RMS of Slit ${ }^{-/-}$mice is also characterized by disturbed neuroblast migration and disorganized RMS astrocytes, similar to what was found in $E p h A 4^{-1-}$ mice. Additionally, the formation of neuroblast chains requires signaling between laminin and $\beta 1$ integrins that promotes cell-cell adhesion, and disruption of $\beta 1$-laminin signaling results in dispersed
RMS neuroblasts and disarrayed RMS astrocytes (Belvindrah et al., 2007). Neuroblast migration is also facilitated by homotypic interactions among cell adhesion proteins, such as PSA-NCAM (Hu et al., 1996; Wichterle et al., 1997). We propose that EphA4 forward signaling works collaboratively with PSA-NCAM and integrins in the control of homotypic neuroblast-neuroblast adhesive interactions that maintain neuroblasts in migratory chains, whereas contact-repulsive events via EphA4 result in the saltatory migration of neuroblasts along the RMS to the OB. Simultaneously, heterotypic EphA4ephrin interactions between neuroblasts and the surrounding astroglial meshwork may help maintain neuroblasts within the RMS or alternatively help to keep astrocytes tightly associated with neuroblast chains. A lack of EphA4 results in fewer neuroblasts efficiently reaching the $\mathrm{OB}$, specifically the periglomerular layer, following a 3 week chase period, suggesting that EphA4-mediated adhesive and/or repulsive homotypic and heterotypic signaling mechanisms that maintain RMS organization and coordinated neuroblast migration are essential for efficient population of interneurons within the OB. Our findings support a model in which EphA4 signaling acts in concert with integrin-laminin and PSA-NCAM as a critical cell-cell adhesion process to reinforce 
the compact nature of the RMS, and together with Slit-Robo signaling, supports neuroblast migration through the dense astroglial meshwork to the OB. Because EphA4 is not expressed on all of RMS neuroblasts and astrocytes, other Eph receptor signaling likely facilitates neuroblast fasciculation and directed migration in the subpopulations that are unaffected EphA4 $4^{-/-}$mice.

The SVZ stem cell niche and the RMS migration pathway form an extraordinary system that facilitates large-scale movement of newborn neurons through mature tissue through the use of unique cytoarchitectural and cell-cell signaling modalities, including Eph-ephrin signaling. Our findings show, for the first time, the distinct importance of EphA4-ephrin signaling in establishing RMS organization and regulated control of neuroblast migration. A better understanding of neuroblast migration and the mechanisms that govern attractive and repulsive events leading to effective neuroblast movement to target destinations extends far beyond the rodent RMS. It is unclear how the infant human RMS, medial migratory stream, and recently characterized Arc migratory stream around the anterior lateral ventricles are organized or the molecular mechanisms that facilitate these distinct neuroblast migration pathways (Sanai et al., 2011; Paredes et al., 2016). Detailed information about the molecular players involved in dictating neuroblast organization and migration in the rodent RMS will inform further studies on neuroblast migration in the developing human brain and ultimately advance therapies associated with fetal brain development.

\section{References}

Alvarez-Buylla A, Lim DA (2004) For the long run: maintaining germinal niches in the adult brain. Neuron 41:683-686. CrossRef Medline

Aoki M, Yamashita T, Tohyama M (2004) EphA receptors direct the differentiation of mammalian neural precursor cells through a mitogen-activated protein kinase-dependent pathway. J Biol Chem 279:32643-32650. CrossRef Medline

Baker KL, Daniels SB, Lennington JB, Lardaro T, Czap A, Notti RQ, Cooper O, Isacson O, Frasca S Jr, Conover JC (2006) Neuroblast protuberances in the subventricular zone of the regenerative MRL/MpJ mouse. J Comp Neurol 498:747-761. CrossRef Medline

Belvindrah R, Hankel S, Walker J, Patton BL, Müller U (2007) Betal integrins control the formation of cell chains in the adult rostral migratory stream. J Neurosci 27:2704-2717. CrossRef Medline

Braun SM, Jessberger S (2014) Adult neurogenesis: mechanisms and functional significance. Development 141:1983-1986. CrossRef Medline

Cameron HA, McKay RD (2001) Adult neurogenesis produces a large pool of new granule cells in the dentate gyrus. J Comp Neurol 435:406-417. CrossRef Medline

Capilla-Gonzalez V, Lavell E, Quiñones-Hinojosa A, Guerrero-Cazares H (2015) Regulation of subventricular zone-derived cells migration in the adult brain. Adv Exp Med Biol 853:1-21. CrossRef Medline

Carvalho RF, Beutler M, Marler KJ, Knöll B, Becker-Barroso E, Heintzmann R, Ng T, Drescher U (2006) Silencing of EphA3 through a cis interaction with ephrinA5. Nat Neurosci 9:322-330. CrossRef Medline

Casper K, McCarthy K (2006) GFAP-positive progenitor cells produce neurons and oligodendrocytes throughout the CNS. Mol Cell Neurosci 31: 676-684. CrossRef Medline

Codega P, Silva-Vargas V, Paul A, Maldonado-Soto AR, Deleo AM, Pastrana E, Doetsch F (2014) Prospective identification and purification of quiescent adult neural stem cells from their in vivo niche. Neuron 82:545559. CrossRef Medline

Conover JC, Todd KL (2016) Development and aging of a brain neural stem cell niche. Exp Gerontol. Advance online publication. Retrieved Nov. 17, 2016. doi: 10.1016/j.exger.2016.11.007. CrossRef Medline

Conover JC, Doetsch F, Garcia-Verdugo JM, Gale NW, Yancopoulos GD, Alvarez-Buylla A (2000) Disruption of Eph/ephrin signaling affects migration and proliferation in the adult subventricular zone. Nat Neurosci 3:1091-1097. CrossRef Medline

Cramer KS, Miko IJ (2016) Eph-ephrin signaling in nervous system development. F1000Res 5.

del Valle K, Theus MH, Bethea JR, Liebl DJ, Ricard J (2011) Neural progen- itors proliferation is inhibited by EphB3 in the developing subventricular zone. Int J Dev Neurosci 29:9-14. CrossRef Medline

Doetsch F, Alvarez-Buylla A (1996) Network of tangential pathways for neuronal migration in adult mammalian brain. Proc Natl Acad Sci U S A 93:14895-14900. CrossRef Medline

Doetsch F, García-Verdugo JM, Alvarez-Buylla A (1997) Cellular composition and three-dimensional organization of the subventricular germinal zone in the adult mammalian brain. J Neurosci 17:5046-5061. Medline

Dudanova I, Klein R (2011) The axon's balancing act: cis- and trans-interactions between Ephs and ephrins. Neuron 71:1-3. CrossRef Medline

Falivelli G, Lisabeth EM, Rubio de la Torre E, Perez-Tenorio G, Tosato G, Salvucci O, Pasquale EB (2013) Attenuation of eph receptor kinase activation in cancer cells by coexpressed ephrin ligands. PLoS One 8:e81445. CrossRef Medline

Gage FH (2000) Mammalian neural stem cells. Science 287:1433-1438. CrossRef Medline

García-Marqués J, De Carlos JA, Greer CA, López-Mascaraque L (2010) Different astroglia permissivity controls the migration of olfactory bulb interneuron precursors. Glia 58:218-230. CrossRef Medline

Gengatharan A, Bammann RR, Saghatelyan A (2016) The role of astrocytes in the generation, migration, and integration of new neurons in the adult olfactory bulb. Front Neurosci 10:149. CrossRef Medline

Gibson JD, Jakuba CM, Boucher N, Holbrook KA, Carter MG, Nelson CE (2009) Single-cell transcript analysis of human embryonic stem cells. Integr Biol (Camb) 1:540-551. CrossRef Medline

Goldshmit Y, McLenachan S, Turnley A (2006) Roles of Eph receptors and ephrins in the normal and damaged adult CNS. Brain Res Rev 52:327345. CrossRef Medline

Helmbacher F, Schneider-Maunoury S, Topilko P, Tiret L, Charnay P (2000) Targeting of the EphA4 tyrosine kinase receptor affects dorsal/ventral pathfinding of limb motor axons. Development 127:3313-3324. Medline

Hirrlinger J, Dringen R (2005) Multidrug resistance protein 1-mediated export of glutathione and glutathione disulfide from brain astrocytes. Methods Enzymol 400:395-409. CrossRef Medline

Holmberg J, Armulik A, Senti KA, Edoff K, Spalding K, Momma S, Cassidy R, Flanagan JG, Frisén J (2005) Ephrin-A2 reverse signaling negatively regulates neural progenitor proliferation and neurogenesis. Genes Dev 19: 462-471. CrossRef Medline

Hu H, Tomasiewicz H, Magnuson T, Rutishauser U (1996) The role of polysialic acid in migration of olfactory bulb interneuron precursors in the subventricular zone. Neuron 16:735-743. CrossRef Medline

Kaneko N, Marín O, Koike M, Hirota Y, Uchiyama Y, Wu JY, Lu Q, TessierLavigne M, Alvarez-Buylla A, Okano H, Rubenstein JL, Sawamoto K (2010) New neurons clear the path of astrocytic processes for their rapid migration in the adult brain. Neuron 67:213-223. CrossRef Medline

Kania A, Klein R (2016) Mechanisms of ephrin-Eph signalling in development, physiology and disease. Nat Rev Mol Cell Biol 17:240-256. CrossRef Medline

Klein R (2001) Excitatory Eph receptors and adhesive ephrin ligands. Curr Opin Cell Biol 13:196-203. CrossRef Medline

Kullander K, Mather NK, Diella F, Dottori M, Boyd AW, Klein R (2001) Kinasedependent and kinase-independent functions of EphA4 receptors in major axon tract formation in vivo. Neuron 29:73-84. CrossRef Medline

Liang Y, Li K, Riecken K, Maslyukov A, Gomez-Nicola D, Kovalchuk Y, Fehse $\mathrm{B}$, Garaschuk O (2016) Long-term in vivo single-cell tracking reveals the switch of migration patterns in adult-born juxtaglomerular cells of the mouse olfactory bulb. Cell Res 26:805-821. CrossRef Medline

Lim DA, Alvarez-Buylla A (2016) The adult ventricular-subventricular zone (V-SVZ) and olfactory bulb (OB) neurogenesis. Cold Spring Harb Perspect Biol 8:5. CrossRef Medline

Lledo PM, Merkle FT, Alvarez-Buylla A (2008) Origin and function of olfactory bulb interneuron diversity. Trends Neurosci 31:392-400. CrossRef Medline

Lois C, García-Verdugo JM, Alvarez-Buylla A (1996) Chain migration of neuronal precursors. Science 271:978-981. CrossRef Medline

Luo J, Daniels SB, Lennington JB, Notti RQ, Conover JC (2006) The aging neurogenic subventricular zone. Aging Cell 5:139-152. CrossRef Medline

Luskin MB (1993) Restricted proliferation and migration of postnatally generated neurons derived from the forebrain subventricular zone. Neuron 11:173-189. CrossRef Medline

Marquardt T, Shirasaki R, Ghosh S, Andrews SE, Carter N, Hunter T, Pfaff SL (2005) Coexpressed EphA receptors and ephrin-A ligands mediate opposing actions on growth cone navigation from distinct membrane domains. Cell 121:127-139. CrossRef Medline 
Martínez A, Soriano E (2005) Functions of ephrin/Eph interactions in the development of the nervous system: emphasis on the hippocampal system. Brain Res Brain Res Rev 49:211-226. CrossRef Medline

Merkle FT, Mirzadeh Z, Alvarez-Buylla A (2007) Mosaic organization of neural stem cells in the adult brain. Science 317:381-384. CrossRef Medline

Nie K, Molnár Z, Szele FG (2010) Proliferation but not migration is associated with blood vessels during development of the rostral migratory stream. Dev Neurosci 32:163-172. CrossRef Medline

O’Neill AK, Kindberg AA, Niethamer TK, Larson AR, Ho HH, Greenberg ME, Bush JO (2016) Unidirectional Eph/ephrin signaling creates a cortical actomyosin differential to drive cell segregation. J Cell Biol 215:217229. CrossRef Medline

Paredes MF, James D, Gil-Perotin S, Kim H, Cotter JA, Ng C, Sandoval K, Rowitch DH, Xu D, McQuillen PS, Garcia-Verdugo JM, Huang EJ, Alvarez-Buylla A (2016) Extensive migration of young neurons into the infant human frontal lobe. Science 354:6308. CrossRef Medline

Pasquale EB (2008) Eph-ephrin bidirectional signaling in physiology and disease. Cell 133:38-52. CrossRef Medline

Peretto P, Giachino C, Aimar P, Fasolo A, Bonfanti L (2005) Chain formation and glial tube assembly in the shift from neonatal to adult subventricular zone of the rodent forebrain. J Comp Neurol 487:407-427. CrossRef Medline

Puschmann TB, Turnley AM (2010) Eph receptor tyrosine kinases regulate astrocyte cytoskeletal rearrangement and focal adhesion formation. J Neurochem 113:881-894. CrossRef Medline

Ricard J, Salinas J, Garcia L, Liebl DJ (2006) EphrinB3 regulates cell proliferation and survival in adult neurogenesis. Mol Cell Neurosci 31:713-722. CrossRef Medline

Sahin M, Greer PL, Lin MZ, Poucher H, Eberhart J, Schmidt S, Wright TM,
Shamah SM, O'Connell S, Cowan CW, Hu L, Goldberg JL, Debant A, Corfas G, Krull CE, Greenberg ME (2005) Eph-dependent tyrosine phosphorylation of ephexin 1 modulates growth cone collapse. Neuron 46:191-204. CrossRef Medline

Sanai N, Berger MS, Garcia-Verdugo JM, Alvarez-Buylla A (2007) Comment on "Human neuroblasts migrate to the olfactory bulb via a lateral ventricular extension." Science 318:393; author reply 393. CrossRef Medline

Sanai N, Nguyen T, Ihrie RA, Mirzadeh Z, Tsai HH, Wong M, Gupta N, Berger MS, Huang E, Garcia-Verdugo JM, Rowitch DH, Alvarez-Buylla A (2011) Corridors of migrating neurons in the human brain and their decline during infancy. Nature 478:382-386. CrossRef Medline

Shamah SM, Lin MZ, Goldberg JL, Estrach S, Sahin M, Hu L, Bazalakova M, Neve RL, Corfas G, Debant A, Greenberg ME (2001) EphA receptors regulate growth cone dynamics through the novel guanine nucleotide exchange factor ephexin. Cell 105:233-244. CrossRef Medline

Theus MH, Ricard J, Bethea JR, Liebl DJ (2010) EphB3 limits the expansion of neural progenitor cells in the subventricular zone by regulating p53 during homeostasis and following traumatic brain injury. Stem Cells 28: 1231-1242. CrossRef Medline

Wichterle H, Garcia-Verdugo JM, Alvarez-Buylla A (1997) Direct evidence for homotypic, glia-independent neuronal migration. Neuron 18:779791. CrossRef Medline

Yin Y, Yamashita Y, Noda H, Okafuji T, Go MJ, Tanaka H (2004) EphA receptor tyrosine kinases interact with coexpressed ephrin-A ligands in cis. Neurosci Res 48:285-296. CrossRef Medline

Zhang L, Li H, Zeng S, Chen L, Fang Z, Huang Q (2015) Long-term tracing of the BrdU label-retaining cells in adult rat brain. Neuroscience letters 591:30-34. CrossRef Medline 